\title{
Education and Stability Learning Journey: Lessons learned and emerging issues
}

Juliet Millican

Institute of Development Studies

March 2021 


\section{About this report}

The K4D Emerging Issues report series highlights research and emerging evidence to policy-makers to help inform policies that are more resilient to the future. K4D staff researchers work with thematic experts and the UKGovernment's Foreign, Commonwealth and Development Office (FCDO) to identify where new or emerging research can inform and influence policy.

This report is based on desk-based research, carried out between July 2020 and January 2021.

K4D services are provided by a consortium of leading organisations working in international development, led bythe Institute of Development Studies (IDS), with the Education Development Trust, Itad, University of Leeds Nuffield Centre for International Health and Development, Liverpool School of Tropical Medicine (LSTM), University of Birmingham International Development Department (IDD) and the University of Manchester Humanitarian and Conflict Response Institute (HCRI).

For any enquiries, please contact helpdesk@k4d.info.

\section{Acknowledgements}

We would like to thank Duncan Edwards, The Tap Room, who provided advice and guidance on the developmentof this report and served as an external expert reviewer. We would also like to thank Rowan and Thomas Wheeler, FCDO, who provided internal reviews for this report.

The content of the report does not necessarily reflect the opinions of any of the experts consulted. Finally, we would like to thank Lewis Small, who copyedited this report.

\section{Suggested citation}

Millican, J. (2021). Education and Stability Learning Journey: Lessons learned and emerging issues. K4DEmerging Issues Report 37. Brighton, UK: Institute of Development Studies. DOI:

$10.19088 / K 4 D .2022 .013$

\section{Copyright}

This report was prepared for the UK Government's Foreign, Commonwealth and Development Office (FCDO) and its partners in support of pro-poor programmes. Except where otherwise stated, it is licensed for non- commercial purposes under the terms of the Open Government Licence v3.0. K4D cannot be held responsible forerrors or any consequences arising from the use of information contained in this report. Any views and opinions expressed do not necessarily reflect those of FCDO, K4D or any other contributing organisation. 


\section{Contents}

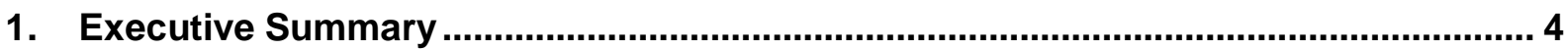

Education and Stability - what do we know? ....................................................... 5

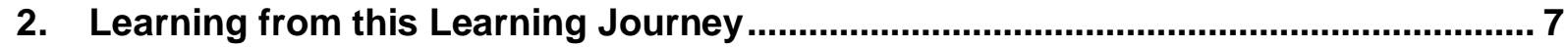

Working with the state/authority actors on education in conflict .................................... 7

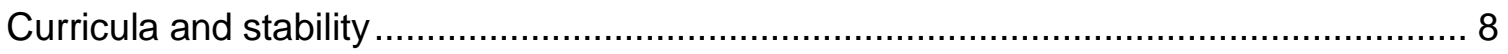

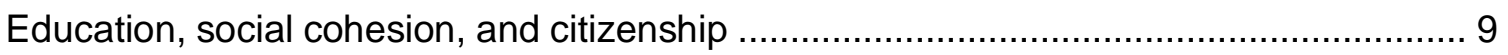

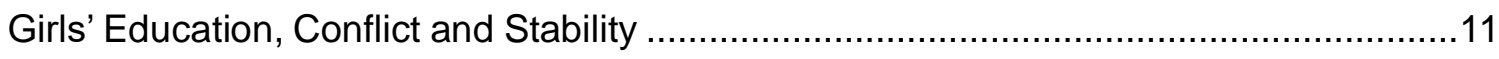

Education and Countering Violent Extremism and Terrorism .......................................11

3. What does this mean for policy and practice? ..................................................... 13

4. The 4Rs Framework: A tool for policy and programmes ........................................... 15

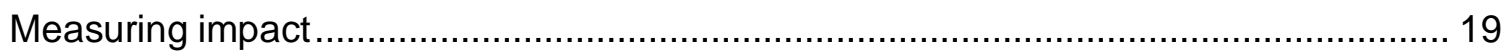

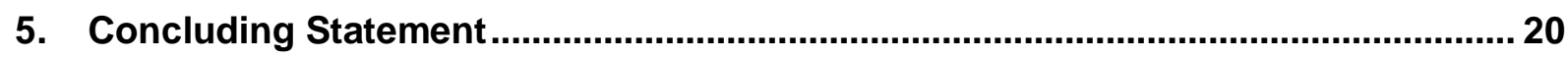

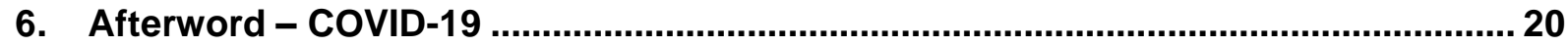

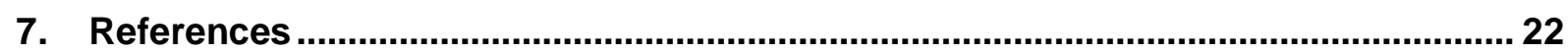




\section{Executive Summary}

This document brings together key findings from a Foreign, Commonwealth and Development Office (FCDO) Learning Journey designed to explore the relationship between education, conflict, and stability. Prepared by the Knowledge, Evidence and Learning for Development Programme (K4D), it responds to questions from FCDO on how education interventions can buildpeace and stability, drawing together research and lessons from FCDO posts, and input from leading academics.

\section{Key messages emerging from this Learning Journey:}

1) Education matters for peace. Systematic study suggests there is a relationship between higher levels of education in a population and decreased levels of violence (Østby et al., 2019). Education, if designed and implemented well, can: act as a peace dividend; strengthen state legitimacy; build social cohesion; decrease propensity for violence, and increase opportunity costs for engaging in violence.

2) At the same time, education can exacerbate conflict. Countries with educational inequalities between identity groups are more likely to experience violent conflict. Education can; be used as a tool of exclusion; negatively affect social cohesion and unsafe educational spaces and increase exposure to violence - see section 2.

3) All education interventions need to be grounded in robust political economy and conflict analyses to ensure a sound understanding of how education interacts with conflict dynamics. Equally, national, or regional political and conflict analyses should consider the role of education in conflict and stability.

4) Avoid instrumentalising education simply as a tool for security: teachers need to build trust and critical thinking, and this is undermined by expectations of surveillance and limitations on freedom. Instead, consider the ways in which a more equitable educational system, designed with a good understanding of the political, social, and economic context, can address roots causes of conflict.

5) Take a pragmatic inter-sectoral approach to maximise opportunities and avoid different departments or interventions working in silos. Work across disciplines to ensure education and conflict work is aligned and capitalise on synergies with other sectors, aiming for holistic systemic change wherever possible.

6) Recognise the links between education and inclusive economic development and that higher levels of education can create expectation of better employment which, if unmet, may create grievances. Working with economic development programming and policy is important to ensure objectives and activity are aligned.

7) Acknowledge unavoidable trade-offs in meeting the needs of different groups, and the pressures around, for example, inclusion of refugees into an already struggling system, providing education to victims of conflict who have missed out on educational opportunities, or returning soldiers, all of whom can be drawn into violent or opposing factions further exacerbating conflict.

8) Aim for nationally owned systemic change rather than piecemeal interventions, while finding ways to operate in states with both stable and unstable conflict-affected areas which may require a regional approach.

9) Consider the importance of different educational sectors, noting which groups access these, aiming to equalise participation in them and recognising the relative contributions each can make to stability.

10) Recommendations set out by the global education agenda (focused on Education for All) are difficult to achieve in situations of extreme instability, and often fail to address inequalities or power imbalances that underpin conflict or the particularities of language, access and equality of opportunity that might make a significant difference. 


\section{Education and Stability - what do we know?}

Education can build stability, but it can also drive conflict. Bush and Saltarelli's (2000) seminal paper on the two faces of education and conflict (summarised in Table 1) captures how education can both mitigate or exacerbate conflict.

Table 1: Ways in which education can exacerbate or mitigate conflict

\section{Positive Face of Education -Mitigating factors}

Conflict-dampening impact of educational opportunity

Nurturing and sustaining anethnically tolerant climate

Education and the desegregation of the mind

Linguistic tolerance

Cultivation of inclusive conceptions of citizenship

The disarming of history

Education for peace

Educational practice as an explicit response to state oppression
The Negative Face of Education Exacerbation factors

The uneven distribution of education as a means of creating or preserving positions of economic, social, and political privilege Education as a weapon in culturalrepression Denial of education as a weapon of war

Education as a means of manipulating history for political purposes

Education serving to diminish self-worth and encourage hate

Segregated education as a means of ensuring inequality, inferiority, and stereotypes

The role of textbooks in impoverishing the imagination of children and thereby inhibiting them from dealing with conflict constructively

Source: Bush and Saltarelli (2000: 34). (c) UNICEF Innocenti Research Centre

\section{Further evidence shows how education can build stability or drive conflict:}

Education lowers the risk of violent conflict. Systematic global studies show that higher education levels in a country's population is linked to a lower risk of conflict, and that the strongest relationship is with secondary education ${ }^{1}$. There is no consensus on why education is pacifying - it is complex and context dependent, and education can also fuel grievances and violence (Bush \& Saltarelli, 2000).

Education can act as a peace dividend. Education provision can be one of the most visible benefits of peace, underpinning the value of peace agreements for all members of society (UNESCO, 2011). Evidence shows, however, that to capitalise on the peace dividend postconflict, education interventions must focus on speed and visibility of service provision (e.g., rather than starting with long-term systems interventions) (Smith Ellison, 2012).

\footnotetext{
Perpetrators of genocide and high-profile terrorist attacks are often well educated - yet systematic study shows that overall, there is little risk in tertiary education and such examples are outliers. See Østby et al., 2019.
} 
Education can help strengthen state legitimacy. State provision of education can boost trust in the state and reduce grievances that fuel violence and rebellion (Smith Ellison, 2012). To be effective, however, service provision must be grounded in good evidence of citizens' perceptions and expectations of state services (e.g., do people expect the state to provide education?) (McCullough \& Papoulidis, 2020). Equally, education can be used by the state and other authority actors as a tool of power and exclusion, and interventions delivered through such actors may exacerbate conflict (Cemmell, 2009).

Education is important for social cohesion. Countries with educational inequalities between identity groups are more likely to experience violent conflict ${ }^{2}$. Observational and project review evidence suggests that certain approaches, such as 'Peace Education', multiple-perspective history teaching, and inter-group contact programmes can help build positive inter-group relations (Burde et al., 2015). Education spaces can also become a focal point for collective effort and dialogue across divides (Burde et al., 2015). However, education can negatively affect cohesion, through politicised and intolerant content (Burde et al., 2015) or by failing to address past conflict as students revert to alternative sources which reinforce one-sided and unevidenced accounts (Østby \& Strand, 2013).

Education can reduce an individual's propensity for violence. Various forms of curricula including 'Peace Education' teach the skills and practices that are conducive to reducing violence, such as critical thinking, rights-based 'citizenship' education, and social and emotional learning (Smith Ellison, 2012). Education also offers an entry point for psychosocial support to those who have experienced trauma during violent conflict, which is often a predictor of violence(INEE, n.d.). Protecting safe education spaces is vital; corporal punishment, sexual and gender-based violence (SGBV) and other forms of violence in school can have damaging psychological and social effects which increases the risk for later victimisation and/or perpetration of violence (thus affecting subsequent generations) (UNESCO, 2011).

\section{Education can increase the opportunity cost for engaging with organised violence.}

Statistical evidence suggests that more years of schooling increase the earning potential for an individual, which in turn increases the economic opportunity cost of leaving school to engage withan armed group (Collier \& Hoeffler, 2004). However, more recent evidence suggests that actual improved employment conditions as a result of skills training does not lower propensity toward engaging with political violence, and rather that positive impacts are due to increased 'economic optimism' (Mercy Corps, 2015). A literature review (Price, 2019) completed prior to this learning journey summarises thestate of discourse and practice in education and conflict.

\footnotetext{
${ }^{2}$ Conflict insensitive programming can exacerbate inequality and grievances. For example, in Liberia during the civil war an NGO hired English speakers in an area where those from a Christian and agriculturalist ethnic group were the only ones able to access education in English. They later found this had been reflected in their recruitment of local staff, resulting in their programmes focusing entirely on agricultural issues, and with no Muslims among the direct beneficiaries or local staff. See Omoeva \& Buckner, 2015
} 


\section{Learning from this Learning Journey}

Five expert panel events were designed to respond to emerging issues. The below issue briefs detail the key points raised and discussed, rather than rigorous evidence evaluations:

\section{Working with the state/authority actors on education in conflict}

Education provision and curriculum design are often understood as sovereign issues; finding ways to negotiate with state bodies, particularly where the state is seen as a conflict actor, or where the state is no longer functioning and education is led by the military, present particular challenges.

It is important to remember that:

International Humanitarian Law can underpin negotiations/interventions as it mandates that education should continue in situations of armed conflict and that schools, staff and students are protected from armed attack. Where militaries are perpetrating abuse against children, debate can be driven by upholding international norms and encouraging governments to instigate a 'safe schools' policy and take seriously their commitment to educating citizens.

Education service provision will not necessarily strengthen state legitimacy and evidence suggests that state service provision does not always affect perceptions of government actors (McCullough \& Papoulidis, 2020). Provision need not be state-centric and state-society relationships need not be the focus of an educational intervention.

Figure 2: Service Delivery and State Legitimacy from Education and Stability Insights from ten years of SLRC research

\section{Service delivery and state legitimacy}

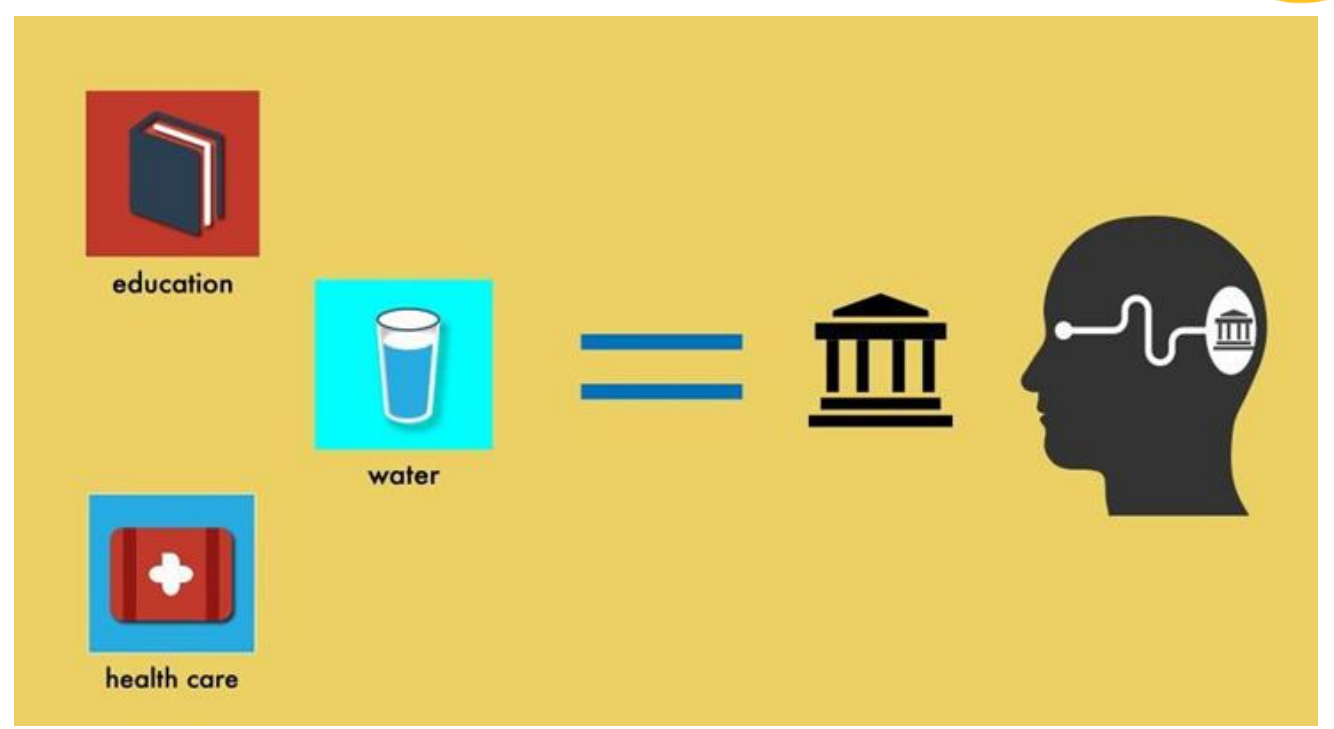

Source: Schomerus, 2020. Secure Livelihoods Research Consortium (SLRC)/ODI. Reproduced with permission 
Governments are heterogonous and should not be viewed as single entities, any engagement with authorities should be based on robust political economy analysis and it is often possible to identify champions within diverse governments. The cultivation of individual relationships is as important as the development of institutional relationships as relationships afford access, information, and influence.

Local education clusters can provide a very valuable group to work with, bringing together key players to look at ways forward and often a more politically neutral and credible voice for advocacy amongst state actors. This can be helpful: as a donor and UK Ministerial department, FCDO must consider wider political implications of supporting or challenging decisions around education.

Female leadership can make a significant contribution to the peace process and the education of girls is crucial to this. Targeted media can help increase demand among parents that their daughters receive an education, working with communities and getting public support is as important as the provision itself in ensuring take up.

Advisors may need to decide whether to prioritise education delivery in the moment over future state strengthening, building a future state through educating people now: This may be dependent on current levels of state fragmentation and the likelihood of a functioning state in the near future.

When there are blockages or challenges in working directly with the state, other forms of education such as community or non-formal provision can help replace or supplement this. Important trade-offs may be needed between state-building and donor coordination objectives with the rapid scaling up of basic services as peace dividends.

\section{Curricula and stability}

Curriculum and textbook design have been seen as sovereign issues, often making it difficult for donors to engage. Supporting text-book writers to create new materials can be an effective intervention with reframing historical content (Davies, 2005), the inclusion of social and emotional learning (NISSEM, 2019) and skills training to improve employability seen as important factors.

Teacher training is as important, as teachers ultimately deliver content and the hidden curriculum (things that are not taught) also impacts student learning. Online learning, greater use of resources from the web, or production of specific resources from agencies can make textbooks quickly out of date, suggesting teacher training may be a more effective intervention.

Skills training for employment must be planned in line with economic development initiatives to ensure training and qualifications are aligned with future job requirements to avoid raising unrealistic expectations for work. In a conflict context this can be volatile and changeable.

Since the 1990s, Peace education (Salomon, 2006) has gradually been introduced as a subject into mainstream curricula in conflict societies, but this needs to be backed up with realistic structural reform and addressing of former grievances. Without this it can be perceived as an imposed or Western initiative, pushing an international peace education 
agenda over the context-specific realities of its teachers, pupils, and local conflict affected communities (Higgins \& Novelli, 2018), suggesting peacebuilding is an individual responsibility. Supporting curricula for peace objectives is a complex and sensitive issue: requiring agreement on what constitutes 'conflict sensitivity' or neutrality in images or content and recognising the trade-offs between the benefits and risks involved. Outside intervention is not always welcome. Governments may resist the inclusion of 'peace education' as a term, recognising the existence of ongoing legitimate conflict and a conflict sensitive approach requires material that is localised, inclusive and equally representative of all social groups and genders.

\section{Somali Region Ethiopia}

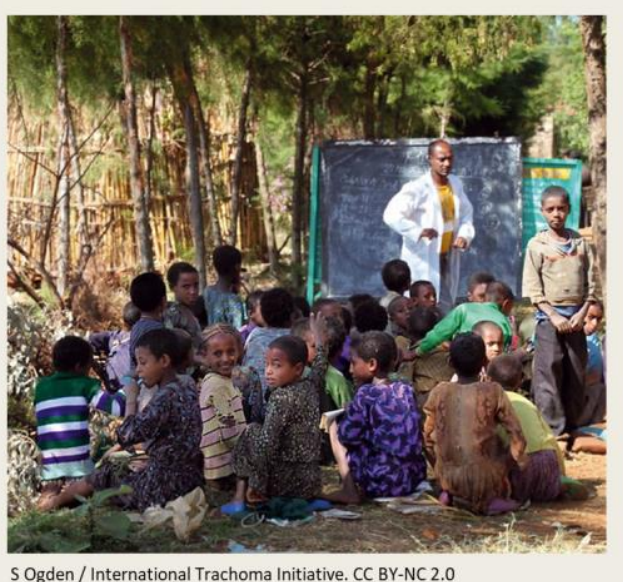

S Ogden / International Trachoma Initiative. CC BY-NC 2.0
Context: Volatile, inter-clan conflict, border with Somalia, predominantly pastoralist societies

- Search for appropriate alternative models of deliver for pastoralist communities - mobile schools

- Curriculum - how relevant to local needs? Whose curriculum?

- Risk of deepening inter-clan conflicts - acute sensitivity to who gets what, where and why?

- Perceived as part of Addis agenda for agropastoralist settlement, threat to traditional way of life

\section{Education, social cohesion, and citizenship}

Building social cohesion involves the development of trust (of others, of the State, of local institutions); of tolerance (of others, of diversity itself); participation (civic and political engagement); and a sense of identity and belonging. In the aftermath of civil conflict citizenship education can contribute to developing a more cohesive society framed around rights and responsibilities.

Promoting social cohesion in a post conflict environment needs to take into account the history of conflict and its subsequent narratives recognising ongoing segregation and the existence of dividers and connectors in society. Social cohesion is not inherently 'good' - and internally socially cohesive groups (far right, fundamentalist, or armed groups) can impact negatively on a broader level. Similarly, citizenship education that promotes trust in a state 
that is corrupt, does not respect human rights, or stresses nationalism and patriotism can further marginalise minority groups.

While there are many advocates for integrated educational programming (McGonigle et al., 2003), integrated education does not always work as communities and parents can fear absorption or erosion of culture and values and strive to protect their identities (McGlynn, 2011).

Table 2: Six Imperatives for Education and Social Cohesion, from webinar

\section{Six imperatives}

1. Solid rights-based education (knowing one's own rights under the law and responsibility to accord the same rights to others)

2. Secular citizenship education that does not conflate government and religion, nor waste too much time learning superficialities about 'others'

3. Critical citizenship education towards complexity in thinking, not black and white, questioning authority

\section{Practice in working together across divides towards a common goal}

5. Need for digital citizenship education, learning about fake news, evidence, who/what to trust

6. Schools as a safe space with no normalisation of violence and revenge

Source: Davies, 2020. Reproduced with permission

\section{Broader Recommendations for Citizenship education include:}

Ensuring Schools can provide a safe space with no normalisation of violence or revenge and where issues of social justice and freedom of expression are understood and practiced. Even in crisis situations it is important to keep schools open as symbols of normality and hope. Schools are often places of safety for young people, especially girls, so promoting well-being and a sense of purpose and worth in life must be seen to carry on. They can also provide valuable opportunities to work in opposition held areas through non-governmental channels.

Supporting curricula to introduce a solid rights-based education, i.e., knowing one's own rights under the law and an awareness of equal rights; the responsibility to accord the same rights to others and a critical attitude to citizenship, involving the practice of participation and active citizenship. 


\section{Girls' Education, Conflict and Stability}

\section{A separate Girls' Education and Conflict paper provides more detail, some key points are:}

Conflict is detrimental to girls' education. Girls are almost 2.5 times more likely to be out of school in conflict-affected countries (UNESCO, 2015). They are also more likely to be out of school than boys ${ }^{3}$. Conflict contexts pose specific barriers to girls' education, including exacerbated SGBV, restricted access to Sexual and Reproductive Health and Rights (SRHR) and increased vulnerability of girls with disabilities (Pereznieto et al., 2017).

Education and safe schools can prevent violence against women and girls (VAWG) in FCAS, girls' education enables women and girls to participate across society and in conflict management and recovery, education is a fundamental right to be protected during conflict and it should be prioritised throughout relief and recovery.

Girls' education enables girls and young women to meaningfully participate across all spheres of society and take a leadership role in peace processes and provides spaces to build social cohesion and underlying grievances.

Girls' education has a specific role to play in supporting long-term peace. Conflict is likely to be more severe and peace more fragile in societies with high levels of gender inequality (Caprioli, 2005). Girls' education promotes female participation across society, enables women to engage in peace processes, and supports women to take leadership roles - all of which are good for peace 4 .

\section{Education and Countering Violent Extremism and Terrorism}

Many factors drive violent behaviour in young people and extreme nationalism, or fundamentalist religions are only a part of bigger picture. Inequality of educational access and outcomes, experiences of racism or discrimination, attacks on identity and broader systemic inequalities all play a significant role.

There is limited evidence for education initiatives in P/CVE. Evidence does suggest that education interventions that do not address local factors of violent extremism can do more harm than good, and that education alone cannot address all drivers of radicalisation.

Evidence further suggests that effective interventions will engage young people in dialogue, equip students with skills of criticism and empathy, and expose them to inclusive narratives and different identities and historical narratives (Wallner, 2020).

Effective approaches to counteracting or preventing extreme and violent behaviour must be designed in context and in response to specific drivers. Financed and accountable nationalaction plans on C/PVE (Davies, 2019a), which include education can make a

3 In 2015, the primary completion rate was $64.5 \%$ for girls in these contexts, compared to $73.5 \%$ for boys, while at the lower secondary level, the completion rate was 39.2\% for girls and 47.2\% for boys. See GPE, 2018.

4 For further information on girls' education see Millican, 2020. 
significant difference. These entail forming partnerships and collaborations across ministries and sectors, to include police, judicial services, and local NGOs, helplines, manuals, local hubs, sustained teacher education and a whole school approach which provide young people with a stake in society and a culture of democracy, respect, and human rights.

\section{Teachers cannot and should not be tasked with addressing extremism beyond building} resilience to grooming and challenging any form of violence in school or notions of masculinity that support violent behaviour. Moral messages or the promotion of 'tolerance' further individualise the problem, ignoring what are often intolerable contexts and underlying causes of extremism (Davies, 2018). Problematic or radical behaviour often emerges from a state's unmet responsibilities towards its citizens.

Key dilemmas include:

- The difference between protection and securitisation and the danger of over-reaction

- The need to recognise the vulnerability of particular groups and the danger of stigmatising

- The value of sanitising curriculum and textbooks in a highly changing context

- Whether to focus on violence rather than 'terrorism'

While education is generally understood to have a pacifying effect on conflict (Østby \& Urdal, 2011), extremism is more likely to be linked to lack of opportunity and unmet expectations than tolack of education, when political or social marginalisation or high national unemployment leave young people with few political, social, or economic opportunities, as indicated in Figure 4. A joined up and holistic approach to tackling violence that de-securitises education is needed, allowing it to exist as a space for critical thinking, debate and discussion that promotes integration, social justice, equity, and realistic opportunity.

Table 3: Key messages for what does and does not work for education and conflict.

\section{What does not work}

- Messages of love and harmony

- Individualistic 'inner peace'

- Religious counter-narratives by(western) governments, telling Muslims what is in the Quran

- Single one-off interventions, however striking and fun

- Strategies that appear to stigmatiseone religious group

- Supressing free speech rather thanallowing uncomfortable views to beaired

\section{What works}

- Teachers have sound preparation in teaching controversial issues

- A full set of recipients is targeted (students, teachers, family, community)

- There is wide consultation (police, religious leaders, social workers)

- There is not just learning about 'other' faiths/cultures but a political understanding of conflict, including religious conflict

- A programme is not moralistic but critical, with a practical and visible outcome - civic engagement, campaigns, production of counternarrative materials, citizen research

Source: Davies (2019b: 76-77). Reproduced with permission. (C) UCL 


\section{What does this mean for policy and practice?}

The evidence shows that education can build, but also undermine stability. At a minimum, interventions must be conflict sensitive and not exacerbate conflict. But in order to build peace and stability, interventions need to go further to intentionally and deliberately address drivers of conflict. This is illustrated in the table below.

Table 4: Education and Conflict Sensitivity

\begin{tabular}{|c|c|c|c|}
\hline \multicolumn{4}{|c|}{ Example activities with level of conflict sensitivity } \\
\hline $\begin{array}{l}\text { Activity } \\
\text { type/Issue }\end{array}$ & $\begin{array}{l}\text { Minimalist, - do no } \\
\text { harm: }\end{array}$ & $\begin{array}{l}\text { Medium - Contribute to } \\
\text { Peace\& Stability }\end{array}$ & $\begin{array}{l}\text { Maximalist, address } \\
\text { drivers of conflict: }\end{array}$ \\
\hline $\begin{array}{l}\text { Level of } \\
\text { ambition }\end{array}$ & $\begin{array}{l}\text { Work for small } \\
\text { achievable goals, e.g., } \\
\text { minimising violence or } \\
\text { the use of inflammatory } \\
\text { language in schools. }\end{array}$ & $\begin{array}{l}\text { Take a longer-term view } \\
\text { of how education can } \\
\text { contribute to stability, with } \\
\text { consideration of broader } \\
\text { societal issues such as } \\
\text { economic inequality. }\end{array}$ & $\begin{array}{l}\text { Take a long-term } \\
\text { approach, integrated with } \\
\text { multisectoral work to } \\
\text { address conflict drivers } \\
\text { e.g., inclusive economic } \\
\text { development. }\end{array}$ \\
\hline $\begin{array}{l}\text { Level of } \\
\text { strategic } \\
\text { cohesion }\end{array}$ & $\begin{array}{l}\text { Work across HMG } \\
\text { departments avoiding a } \\
\text { siloed approach to } \\
\text { maximise opportunities } \\
\text { and avoid interventions } \\
\text { that undermine each } \\
\text { other. } \\
\text { Build connections in } \\
\text { government with } \\
\text { ministers of education. }\end{array}$ & $\begin{array}{l}\text { Expand local involvement } \\
\text { throughparental groups } \\
\text { andcreation } \\
\text { of/engagement with local } \\
\text { councils. } \\
\text { Work closely with other } \\
\text { donors and host } \\
\text { government on education } \\
\text { and stability strategy. }\end{array}$ & $\begin{array}{l}\text { Work towards a systemic } \\
\text { joined up approach } \\
\text { owned at national level, } \\
\text { driving future change, and } \\
\text { working towards } \\
\text { transparency and } \\
\text { accountability in } \\
\text { governance. }\end{array}$ \\
\hline $\begin{array}{l}\text { Level of } \\
\text { analysis }\end{array}$ & $\begin{array}{l}\text { Use a conflict analysis } \\
\text { or political economy } \\
\text { analysis to avoid } \\
\text { exacerbating existing } \\
\text { conflict drivers. } \\
\text { Incorporate education } \\
\text { into conflict analyses. }\end{array}$ & & $\begin{array}{l}\text { Conduct a full review of } \\
\text { education and conflict, for } \\
\text { example using the 4Rs } \\
\text { framework. }\end{array}$ \\
\hline \multicolumn{4}{|c|}{ Intervention examples } \\
\hline $\begin{array}{l}\text { Inclusion } \\
\text { and social } \\
\text { cohesion }\end{array}$ & $\begin{array}{l}\text { Ensure some kind of } \\
\text { schooling continues for } \\
\text { children, with particular } \\
\text { protection for girls in } \\
\text { violent contexts. }\end{array}$ & $\begin{array}{l}\text { As far as possible avoid } \\
\text { exclusion through specific } \\
\text { language use or regional } \\
\text { provision. } \\
\text { Fill gaps in education } \\
\text { through provision for }\end{array}$ & $\begin{array}{l}\text { Ensure equality of } \\
\text { opportunity across } \\
\text { different educational } \\
\text { sectors, with equal } \\
\text { participation and } \\
\text { representation. }\end{array}$ \\
\hline
\end{tabular}




\begin{tabular}{|l|l|l|l|}
\hline refugees (Garnett Russell & $\begin{array}{l}\text { Address structural } \\
\text { et al., 2020) or } \\
\text { accelerated learning } \\
\text { programmese.g., } \\
\text { Afghanistan (Awad, 2019). }\end{array}$ & $\begin{array}{l}\text { inequalities underlying in } \\
\text { education, responding to } \\
\text { rather than punishing } \\
\text { legitimate grievances. }\end{array}$ \\
\hline Curriculum & $\begin{array}{l}\text { Ensure that any } \\
\text { interventions do not } \\
\text { result in more divisive } \\
\text { or militant attitudes to } \\
\text { become prevalent in } \\
\text { curricula. }\end{array}$ & $\begin{array}{l}\text { Engage with providers of } \\
\text { curriculum to reduce } \\
\text { militant and divisive } \\
\text { narratives and increase } \\
\text { representation of minority } \\
\text { groups. }\end{array}$ & $\begin{array}{l}\text { Review or support the } \\
\text { rewriting of curricula and } \\
\text { textbooks to remove } \\
\text { biased historical accounts } \\
\text { and promote education } \\
\text { for citizenship(Quaynor, }\end{array}$ \\
\hline & $\begin{array}{l}\text { 2012). } \\
\text { Provide conflict sensitive }\end{array}$ \\
\hline $\begin{array}{l}\text { Working } \\
\text { across } \\
\text { fragmented } \\
\text { conflict } \\
\text { contexts }\end{array}$ & $\begin{array}{l}\text { Consider localised } \\
\text { issues and adapt } \\
\text { programmes and policy } \\
\text { accordingly. }\end{array}$ & $\begin{array}{l}\text { Target interventions at } \\
\text { more at risk areas using } \\
\text { non-formal education } \\
\text { where there is no state } \\
\text { provision. }\end{array}$ & $\begin{array}{l}\text { teacher recruitment and } \\
\text { training in managing } \\
\text { difference (Kasumagić- } \\
\text { Kafedžić, 2017). }\end{array}$ \\
\hline $\begin{array}{l}\text { Aim to build sustainable } \\
\text { education in at risk areas, } \\
\text { perhaps through non- } \\
\text { state provider networks. }\end{array}$
\end{tabular}

Source: Author's own. Adapted from Davies, 2019b. 


\section{The 4Rs Framework: A tool for policy and programmes}

The 4Rs (Novelli et al., 2017) framework draws on Nancy Fraser's (2009) models of Social Justice and Galtung and Fischer's (2013) concept of a positive peace, to look at how education can interact with the underlying drivers and legacies of conflict ${ }^{5}$.

It is useful to:

- Understand how existing educations systems in-country interact with drivers of conflict

- Analyse how existing education programmes and interventions may be contributing to addressing the drivers of conflict, drawing out the contribution of the programme to stability

- Design education programmes and interventions to intentionally address drivers of conflict

Figure 4: The 4Rs framework.

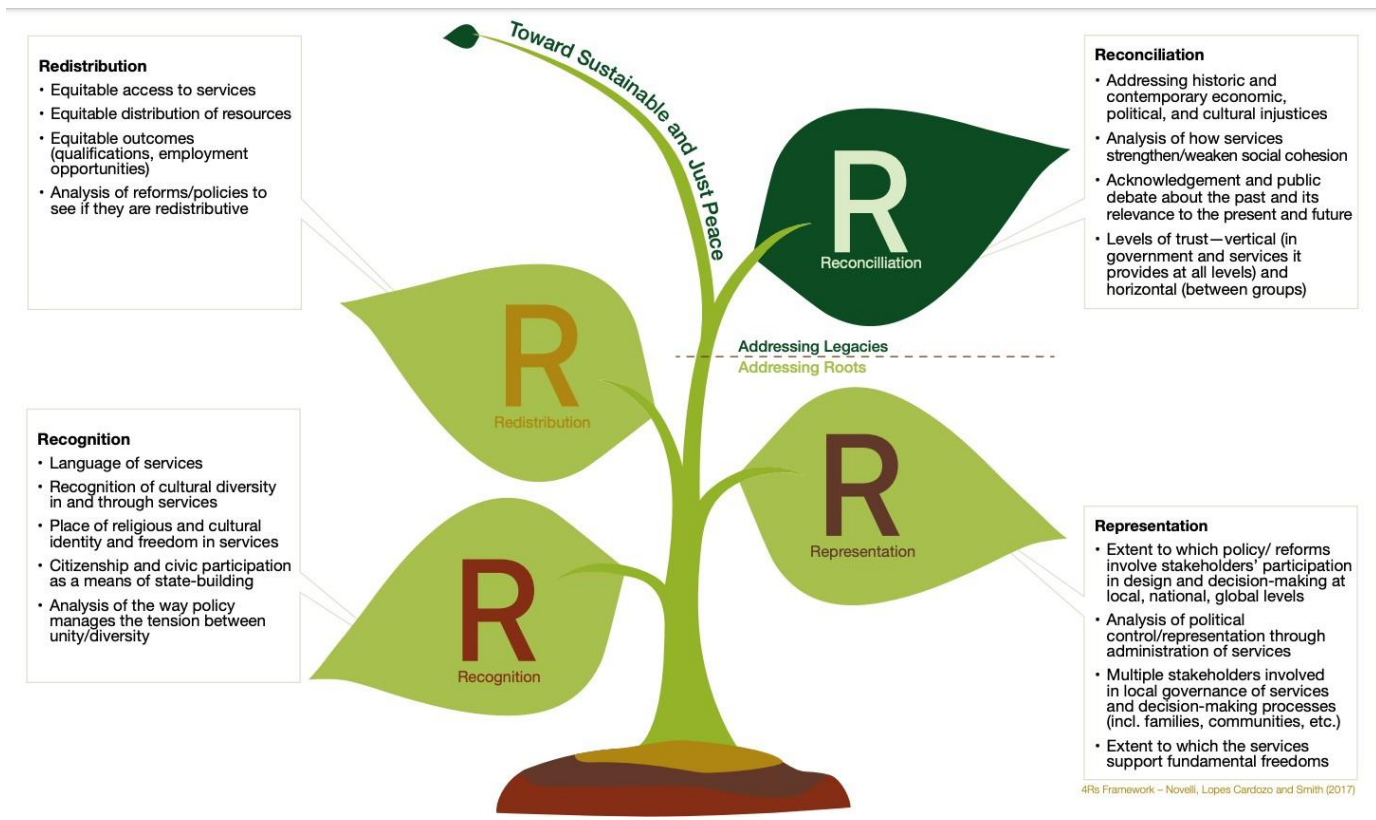

Source: Novelli et al., 2019. Reproduced with permission

\section{Redistribution}

Redistribution interventions include addressing issues of:

- Access, resources, outcomes, employment opportunities (e.g., Kenya)

- Macro reforms such as decentralisation (e.g., Bosnia) or privatisation (e.g., Uganda)

- Policies around teacher recruitment, employment, and deployment (e.g., Nepal)

- Citizenship and civic education as a means of state-building

5 The 4 Rs must be understood relationally. There can be tensions between the first 3Rs (redistribution, recognition, and representation) which look to identify and reduce the "drivers of conflict," and reconciliation which is more focused on addressing the "legacies of conflict". 
Challenges include dangers associated with the introduction of privatisation which might add to the indifference of the state towards tackling poor quality education only available for those who cannot afford private schooling; and the difficulty of improving governance in areas where a lack of accountability, corruption, informal governance, and failures in policy implementation are commonplace, all of which potentially fuel further conflict.

\section{Redistribution in South Sudan}

Clear inequalities in access, resources and outcomes exist in the education system in South Sudan. The relationship between inequity in education and conflict is reflected by regions ofthe country with the highest occurrence of conflict events since 2011 (Unity, Upper Nile, Jonglei) have the lowest provision of educational resources and the lowest percentage of students in upper primary (Novelli et al., 2016). A range of policies and programmes have been aimed at addressing different dimensions of South Sudan's educational inequity. However, specific policy strategies reflect the influence of global education agendas such as girls' education and students with disabilities, rather than contextspecific dimensions of inequity linked to conflict in South Sudan, which include 'pastoralist' communities and older youth. Implementing strategies to address these context-specific existing inequities could help to reduce conflict and ensure equitable access to education opportunities (Novelli et al., 2016).

Further reading: Novelli, M., Daoust, G., Selby, J., Valiente, O., Scandura, R., Deng K., Luka B. \& Salter, E. (2016). Exploring the linkages between education sector governance, inequity, conflict, and peacebuilding in South Sudan. Project report. United Nations Children's Fund, Nairobi, Kenya.http://sro.sussex.ac.uk/id/eprint/61951/1/

smbhome.uscs.susx.ac.uk_dm50_Desktop_file.pdf

\section{Recognition}

Recognition interventions include addressing issues of:

- Language policies and the dominant language of education (e.g., Myanmar, Sri Lanka)

- Inclusion of minorities and ways to ensure this (e.g., Kenya)

- Revision of curriculum content to reflect minority groups (e.g., Pakistan)

Challenges in implementing these include how to support marginalised groups to assert their identities in policy, curriculum, and pedagogical reforms (e.g., language, histories, cultural values and local economies and geographies) and difficulties in articulating their rights to recognition, existing political structures and the location of power, and the danger that any sense of recognition offered could be viewed as tokenistic. 


\section{Language policies and recognition in Myanmar}

Language of education policies can offer recognition of linguistic diversity and offer routes to greater representation of ethnic minority graduates in governance processes. However, opening up to diverse languages can risk reconciliation efforts by causing grievances depending on which languages are chosen as languages of instruction and which are not.

Myanmar is culturally and linguistically diverse with over 100 languages spoken by $30 \%$ of the population (Wong, 2019). The promotion of Burmese is seen by the state as a powerful tool for promoting national unity and ensuring political stability. In 2014 , language of instruction policies led to student protests with the lack of educational resources and opportunities in the local language is perceived as a frustration and unfair treatment of those who speak minority languages. The recognition of local languages through various forms of education can support lessening such frustrations. The government, in partnership with UNICEF, developed a Language Enrichment Programme that includes textbooks and teachers' manuals for some of the national regional languages and to teach these languages out of school hours in Grades 1-4(Smith et al, 2016).

Further reading: Wong, M. (2019). The Peace Dividend of Valuing Non-Dominant Languages in Language-in-Education Policies in Myanmar. FIRE: Forum for International Research in Education. 5. https://fire-ojs-ttu.tdl.org/fire/index.php/FIRE/article/view/143

Smith, A., Datzberger, S., \& McCully, A. (2016). The Integration of Education and Peacebuilding:Synthesis Report on Myanmar, Pakistan, South Africa and Uganda. UNICEF. Pages 76-78

https://pure.ulster.ac.uk/ws/portalfiles/portal/11549188/Smith\%2C+Datzeberger\%2C+McCully+\%282016\%29 + Policy+Synthesis+Report.pdf

\section{Representation}

Representation interventions include addressing issues of

- Governance in administration (e.g., Bosnia)

- School governance (there are various models)

- Supporting curriculum reform processes

Challenges in implementing these include how to reframe representation and rebalance the distribution of power across and between different groups; ensuring that representation is meaningful, (which requires more than ensuring participation of these groups as marginal voices are often suppressed or manipulated and meritocracy can over power equity), avoiding elite capture in processes of decentralisation and ensuring that equitable representation does not further fuel instability. Teachers, school management committees and civil societies are not necessarily pro-transformation and careful scrutiny is needed over who is representing these different groups. 


\section{Kenyan devolution - an opportunity for representation in education sector governance?}

The Kenyan 2010 Constitutional reforms opened up space for devolution of education and administration from the national to the county level. However, partial devolution has resulted in parallel systems of governance at the county level and a number of conflicts have arisen, particularly in relation to the employment and management of teachers.

Devolution has the potential to help to address regional and ethnic inequities and marginalisation - a root cause of conflict in Kenya - but care is needed to avoid increasing tribal divisions and politicisation, bad governance and corruption is not simply replicated and decentralised to the counties. Current challenges in decentralisation of education include a lack of community participation, oversight, and accountability. Without more participatory and representative governance there is a risk that rather than transforming existing inequalities, existing systems of political patronage and favouritism are maintained.

Further reading: Smith, A., Marks, C., Novelli, M., Valiente, O., \& Scandurra, R. (2016). The links between Equity, Governance, Education and Peacebuilding in Kenya. UNICEF UK.

https://www.ulster.ac.uk/ data/assets/pdf_file/0005/237857/Kenya-and-South-Sudan-compressed.pdf

\section{Reconciliation}

Reconciliation interventions include:

- Education recommendations in TRC processes (e.g., Peru, Guatemala)

- Challenging violence as a social norm (e.g., Burundi)

- Revising History textbooks (e.g., Bosnia, but many other examples)

Challenges in implementing these include contested interpretations of the causes of conflict, managing emotive historical memories and encouraging forgiveness in situations where there has been no reparation and feelings of injustice persist. Those who control power often tend to monopolise the terms of reconciliation, and governments prioritise economic recovery over mending social fabric and promoting social cohesion.

\section{Reconciliation example}

A study in History Education and Conflict Transformation (Psaltis et al., 2017) reviewed 127 projects implemented by more than 60 organisations in 45 countries involved writing history booksor textbooks; oral history projects; lectures, seminars, conferences, and workshops, etc, many of which focused on teaching history in school settings. Most effective from a reconciliation perspective were those that encouraged historical thinking where multiperspectivity is especially emphasised as students learn how to analyse, interpret, and reconstruct historical events from a variety of perspectives.

Research in Bosnia has shown how teachers in different areas have access to different curricula and materials, and while textbooks have been rewritten since the war many are single perspectiveand a neutral recounting of facts rather than an attempt to introduce a critical thinking element. Universities responsible for teacher training therefore have a crucial role to play in educating teachers in how to deal with different materials and encourage students in accessing their own resources.

\section{Further reading: Facing History and Ourselves website}

Kasumagić-Kafedžić, L. (2017). Exploring Challenges and Possibilities in Pre-Service Teacher Education: Critical and Intercultural Pedagogy in Post-Conflict Bosnia and Herzegovina. In Challenges Associated with Cross-Cultural and At-Risk Student Engagement. 42-62. IGI Global. 
The paper The '4 Rs' as a tool for critical policy analysis of the education sector in conflict affected states (Novelli et al., 2019) provides a fuller explanation of the framework and how itcan be used as an analytical tool.

\section{Measuring impact}

The 4Rs framework is similarly useful as a tool to measure interventions towards social justice. Table 5 below indicates ways in which interventions might be measured in relation to these three criteria. The 4Rs include the addition of Reconciliation as a move towards peacebuilding, but for some contexts the management of conflict and a reduction in violence is a more realistic goal in relation to stability, with epistemic or historic justice and peacebuilding still a distant aspiration.

Table 5: To what extent is education contributing to sustainable peacebuilding? The 4Rs in practice

\begin{tabular}{|c|c|}
\hline & $\begin{array}{l}\text { To what extent is education contributing to sustainable peacebuilding } \\
\text { (4Rs)? }\end{array}$ \\
\hline $\begin{array}{l}\text { Redistribution } \\
\text { (addressing } \\
\text { inequalities) }\end{array}$ & $\begin{array}{l}\text { What quantitative analysis already exists of data examining vertical } \\
\text { and horizontal inequalities relevant to education inputs, resources, } \\
\text { and outcomes? How can this be used to redirect resources? } \\
\text { - How far are current and recent macro education reforms or policies } \\
\text { redistributive; how might, for example, decentralisation or privatisation } \\
\text { decisions impact different groups and affect conflict dynamics. }\end{array}$ \\
\hline $\begin{array}{l}\text { Recognition } \\
\text { (respecting } \\
\text { difference) }\end{array}$ & $\begin{array}{l}\text { - What is national policy around language of instruction, and who does } \\
\text { this advantage/marginalise/ignore? } \\
\text { - How is cultural diversity expressed in different parts of the curriculum } \\
\text { and curricula materials? } \\
\text { - How does recognition of religious identities and religious diversity } \\
\text { - How far are gendered relations and norms reproduced or challenged } \\
\text { in the education system? } \\
\text { - How might the curriculum approach issues of citizenship, civic } \\
\text { education, sexuality and personal and social education and history } \\
\text { education and how do/should these reflect aspirations for state- } \\
\text { building? }\end{array}$ \\
\hline $\begin{array}{l}\text { Representation } \\
\text { (ensuring } \\
\text { participation) }\end{array}$ & $\begin{array}{l}\text { Who is able to participate in or contribute to the development of } \\
\text { education policy and reforms at local, national, and global levels? } \\
\text { Who has a say in issues of school governance, school-based } \\
\text { management, and the administration of institutional and national } \\
\text { decisions (teachers, parents, students, civil society)? }\end{array}$ \\
\hline
\end{tabular}

\footnotetext{
${ }^{6}$ The questions below are examples and should be used in relationship to each other to examine programming
} contexts 
- How far does the education system support fundamental freedoms, including equal gender representation and recognition of religious minorities?

Reconciliation (dealing with the legacies of the conflict)
- To what extent are historical and contemporary economic, political, and sociocultural injustices underpinning conflict redressed in/through education (e.g., quota systems, school relocation, textbooks, teacher allocation).

- How does education contribute to integration and segregation or social cohesion through separate or integrated school systems and buildings.

- What is or should be taught about the past and its relevance to the present and future?

- How far are educational activities linked to work of truth and reconciliation committees for example, or NGO peacebuilding initiatives?

- What levels of trust exist (e.g., vertical through trust in schools and the education system, or horizontal through trust between different identity-based groups?

Source: Adapted from a presentation to FCDO and based on Novelli, M., Lopes Cardozo, M. and Smith, A. (2017) 'The 4R's Framework: Analysing the Contribution of Education to Sustainable Peacebuilding in Conflict-Affected Contexts.' Journal on Education in Emergencies, 3(1): 14-43. Reproduced with permission.

\section{Concluding Statement}

Education can both build stability and drive conflict. How education interventions are designed and implemented is critically important for effectively addressing conflict drivers and building peace and stability. This involves:

- Seeing building peace and stability as a deliberate objective of interventions, rather than just seeing conflict as a risk to be mitigated through a minimalist conflict sensitivity approach.

- Grounding programmes in good conflict and political economy analysis.

- Recognising where trade-offs exist, and often going with the more challenging, but ultimately more impactful option.

\section{Afterword - COVID-19}

While much of the above research and discussions took place prior to or during the early stages of the COVID-19 pandemic, the implications of this for education and stability were already becoming clear by the end of this learning journey. Research carried out by Yusuf Sayed into the development of education policy in the global south and the impact of COVID19 (IDS, 2021) highlighted how changes brought by the pandemic could significantly impact education policy intothe future. A discussion between Sayed and Pherali as part of this learning journey (IDS, 2021) highlighted how many of these impacts could further undermine 
education's ability to positively influence stability. Key points emerging from this discussion included:

Incidences of policy imposition with proper consultation as education ministers make emergency decisions about how to adapt to the pandemic, threaten recommendations aroundthe importance of proper representation.

A shift to a focus on content rather than the processes of learning, caused by online delivery, missed education and catch-up programmes, threaten recommendations around the importance of psychosocial and process-oriented elements of learning and the development of critical thinking and interpersonal skills.

A lack of teacher preparation or proper teacher training for online pedagogies deskills teachers and undermines recommendations around alternative pedagogies and equipping teachers to deal with trauma and incidences of violence.

A shift to increasingly privatised and online delivery to supplement closed state schools further threatens moves to support state education where possible and ensure equality of access to provision.

Large numbers of children being out of school for extended periods and the likelihood thatsome may never return threatens recommendations for increasing girls' access to and participation in education but also makes girls and boys vulnerable to recruitment by extremist groups.

Sayed's prediction was that many of the changes brought about suddenly by the pandemic would not disappear as quickly, nor automatically as the pandemic subsides. While his recommendations did not provide easy answers to any of the above, they did set out a way to think about what these might be and how programmers might respond in fragile, or conflict affected contexts. Seeing building peace and stability as integral to interventions, grounding programmes in a thorough conflict and political economy analysis and recognising and calculating trade-offs become even more important. 


\section{References}

Awad, M. (2019). Accelerated learning centres transform girls lives: restoring hope to girls' andyoung women's lives. UNICEF. https://www.unicef.org/afghanistan/stories/acceleratedlearning-centers-transform-girls-lives

Burde D., Guven O., Kelcey J., Lahmann H. \&, Al-Abbadi K. (2015). What Works to Promote Children's Educational Access, Quality of Learning, and Wellbeing in Crisis-Affected Contexts. Education Rigorous Literature Review. UK Department for International Development (DFID).

https://assets.publishing.service.gov.uk/government/uploads/system/uploads/attachment_data /file/470773/Education-emergencies-rigorous-review2.pdf

Bush, K. D., \& Saltarelli, D. (2000). The two faces of education in ethnic conflict: Towards a peacebuilding education for children. Research Report. UNICEF Innocenti ResearchCentre. https://www.unicef-irc.org/publications/pdf/insight4.pdf

Caprioli, M. (2005). Primed for Violence: The Role of Gender Inequality in Predicting Internal Conflict. International Studies Quarterly, [online] 49(2), 161-178

https://www.amherst.edu/media/view/233359/original/

Cemmell, J. (2009). Academic Freedom International Study: Burma, Colombia, Israel, Palestine,Zimbabwe. University and College Union (UCU).

https://www.ucu.org.uk/media/3423/Academic-Freedom-International-Study-Colombiachapter/pdf/acdemic_freedom_colombia.pdf

Collier, P., \& Hoeffler, A. (2004). Greed and grievance in civil war. Oxford Economic Papers, 56(4), 563-595. http://www.jstor.org/stable/3488799

Cunningham, R. (2020, March 23). Education and Social Cohesion [Presentation]. Panel 2, Curricula and Stability. Education and stability Learning Journey, UK Foreign,

Commonwealth \& Development Office (FCDO) and Knowledge, Evidence and Learning for Development (K4D).

Davies, L. (2005). Schools and war: Urgent agendas for comparative and international education. Compare: A Journal of Comparative and International Education, 35(4), 357-371.

https://www.tandfonline.com/doi/citedby/10.1080/03057920500331561?scroll=top\&need Access $=$ true

Davies, L. (2018). Review of educational initiatives in counter-extremism internationally. The Segerstedt Institute. https://www.gu.se/sites/default/files/2020-03/1673173_review-ofeducational-initiatives-180110.pdf

Davies, L. (2019a). Education and Radicalisation Prevention: Different Ways Governments can support schools and teachers in preventing/countering violent extremism. Radicalisation Awareness Network, Amsterdam. https://ec.europa.eu/home-

affairs/sites/homeaffairs/files/what-we-

do/networks/radicalisation_awareness_network/about-ran/ran-

edu/docs/ran_edu_different_ways_governments_can_support_schools_teachers_05201 
9_en.pdfDavies, L. (2019b). Education and violent extremism: Insights from complexity theory. Educationand Confict Review, 2, 76-80.

https://discovery.ucl.ac.uk/id/eprint/10081477/1/Education\%20and\%20Conflict\%20Revie w_2019_2_final.pdf

Davies, L. (2020, March 23). Education and Social Cohesion [Webinar]. Panel 2, Curricula andStability. Education and stability Learning Journey, UK Foreign, Commonwealth \& Development Office (FCDO) and Knowledge, Evidence and Learning for Development (K4D).

Fraser, N. (2009). Social justice in the age of identity politics. In G. L. Henderson \& M. Waterstone (Eds.), Geographic Thought: A Praxis Perspective (pp. 72-91). Routledge. https://philpapers.org/rec/FRASJI

Galtung J., Fischer D. (2013) Positive and Negative Peace. In: Johan Galtung.

SpringerBriefs onPioneers in Science and Practice, vol 5. Springer. https://link.springer.com/chapter/10.1007/978-3-642-32481-9_17\#citeas

Garnett Russell, S., Buckner, E., \& Horsch Carsley, S. (2020). The diffusion of global discourses:the case of educating refugees, British Journal of Sociology of Education, 41:7, 992- 1012.

https://www.tandfonline.com/doi/abs/10.1080/01425692.2020.1799752?journalCode=cbs e20

GPE (2018). Results report 2018. Global Partnership for Education (GPE).

https://www.globalpartnership.org/content/results-report-2018

Higgins, S., \& Novelli, M. (2018). The potential and pitfalls of peace education: a cultural politicaleconomy analysis of the emerging issues teacher education curriculum in Sierra

Leone. Asian Journal of Peacebuilding, 6 (1). pp. 29-53.

http://sro.sussex.ac.uk/id/eprint/76922/

IDS (2021). Watch: Covid-19 and development: education policy in the Global South. Institute ofDevelopment Studies (IDS). https://www.ids.ac.uk/events/covid-19-anddevelopment- education-policy-equity-quality-in-the-global-south1/

INEE (n.d.) Psychosocial Support and Social and Emotional Learning (PSS and SEL). https://inee.org/collections/psychosocial-support-and-social-and-emotional-learning

Kasumagić-Kafedžić, L. (2017). Exploring Challenges and Possibilities in Pre-Service Teacher Education: Critical and Intercultural Pedagogy in Post-Conflict Bosnia and Herzegovina.In Challenges Associated with Cross-Cultural and At-Risk Student Engagement, 42-62.IGI Global. https://www.igi-global.com/chapter/exploring-challenges-andpossibilities-in-pre-service-teacher-education/173073

Lenzen, M. (2016). Building Stability Framework 2016. UK Department for International Development (DFID).

https://assets.publishing.service.gov.uk/media/5968990ded915d0baf00019e/UK-AidConnect-Stability-Framework.pdf 
Mercy Corps (2015). Does Youth Employment Build Stability? Evidence from an Impact Evaluation of Vocational Training in Afghanistan. Mercy Corps.

https://www.mercycorps.org/sites/default/files/2020-

01/MercyCorps_AfghanistanINVEST_ImpactEvaluation_2015.pdf

McCullough, A. \& Papoulidis, J. (2020). Why we need to rethink our understanding of state legitimacy to address fragility. World Bank Blogs.

https://blogs.worldbank.org/dev4peace/why-we-need-rethink-our-understanding-statelegitimacy-address-fragility

McGonigle, J., Smith, A., \& Gallagher, T. (2003). Integrated Education in Northern Ireland. The Challenge of Transformation. UNESCO Centre, Ulster University. http://arrts.gtcni.org.uk/gtcni/bitstream/2428/6010/1/The\%20Challenge\%20of\%20Transfo rmation.pdf

McGlynn, C. (2011). Negotiating difference in post-conflict Northern Ireland: An analysis of approaches to integrated education. Multicultural Perspectives, 13(1), 16-22.

https://pure.qub.ac.uk/en/publications/negotiating-difference-in-post-conflict-northern-irelandan-analy

Millican, J. (2020, November 11). Girls' Education and Conflict [Policy Brief]. UK Foreign, Commonwealth \& Development Office (FCDO).

NISSEM (2019). NISSEM Global Briefs: Educating for the social, the emotional and the sustainable. NISSEM. https://www.nissem.org/NGB1

Novelli, M., Daoust, G., Selby, J., Valiente, O., Scandura, R., Deng K., Luka B. \& Salter, E. (2016). Exploring the linkages between education sector governance, inequity, conflict, and peacebuilding in South Sudan. Project eport. United Nations Children's Fund (UNICEF), Nairobi, Kenya. http://sro.sussex.ac.uk/id/eprint/61951/

Novelli, M., Lopes Cardozo, M. \& Smith, A. (2017). The 4Rs framework: analyzing education'scontribution to sustainable peacebuilding with social justice in conflict-affected contexts. Journal on Education in Emergencies, 3 (1), 14-43.

http://sro.sussex.ac.uk/id/eprint/69179/

Novelli, M., Lopes Cardozo, M. \& Smith, A. (2019). The '4 s' as a tool for critical policy analysisof the education sector in conflict affected states. Education and Conflict Review, 2 , $70-$

\section{5. https://discovery.ucl.ac.uk/id/eprint/10081589/}

Omoeva, C. \& Buckner, E. (2015). Does horizontal education inequality lead to violent conflict? Aglobal analysis. Fhi360.

https://www.epdc.org/sites/default/files/documents/FHI360- Horizontal-Inequality-andConflict-Quantitative-Study-20150406-Final1.pdf

Østby, G., \& Strand, H. (2013). Horizontal inequalities and internal conflict: The impact of regimetype and political leadership regulation. In K. Kalu, U. O. Uzodike, \& D. Kraybill (Eds.), Territoriality, citizenship, and peacebuilding, (pp. 139-188). Adonis \& Abbey. 
Østby, G., \& Urdal, H. (2011). Education and civil conflict: A review of the quantitative, empirical literature. Background paper for the Education for All Global Monitoring Report 2011, Thehidden crisis: armed conflict and education. UNESCO.

Østby, G., Urdal, H. \& Dupuy, K. (2019). Does Education Lead to Pacification? A Systematic Review of Statistical Studies on Education and Political Violence, Review of Educational Research, 89(1), 46-92.

Pereznieto, P., Magee, A. \& Fyles, N. (2017). Mitigating threats to girls' education in conflictaffected contexts: current practice. ODI and UNGEI.

https://www.ungei.org/publication/mitigating-threats-girls-education-conflict-affected-contextscurrent-practice

Price, R. (2019). Lessons learned from education programmes' contribution to peace and stability. K4D Helpdesk Report 577. Brighton, UK: Institute of Development Studies. https://opendocs.ids.ac.uk/opendocs/handle/20.500.12413/14482

Psaltis, C. Carretero, M. \& Čehajić-Clancy, S. (2017). History Education and Conflict Transformation: Social Psychological Theories, History Teaching and Reconciliation.Springer. https://link.springer.com/book/10.1007/978-3-319-54681-0

Quaynor, L. J. (2012). Citizenship education in post-conflict contexts: A review of the literature. Education, Citizenship and Social Justice, 7(1), 33-57.

https://journals.sagepub.com/doi/abs/10.1177/1746197911432593?journalCode=esja

Rowan, P. (2020). Five Pillars of the Building Stability framework. [Unpublished]. Salomon, G. (2006). Does peace education really make a difference? Peace and Conflict:Journal of Peace Psychology, 12(1), 37-

48.https://www.tandfonline.com/doi/abs/10.1207/s15327949pac1201_3

Schomerus, M. (2020, February 5). The State, Education and Stability Insights from ten years ofSLRC research [Presentation]. Panel 2, Secure Livelihoods Research Consortium.

Education and stability Learning Journey, UK Foreign, Commonwealth \& Development Office (FCDO) and Knowledge, Evidence and Learning for Development (K4D).

Smith, A. (2020, July 16). Applications of the 4Rs Framework [Presentation]. Launch event forthe Education and stability Learning Journey, UK Foreign, Commonwealth \& Development Office (FCDO) and Knowledge, Evidence and Learning for Development(K4D).

Smith, A., Datzberger, S., \& McCully, A. (2016). The Integration of Education and Peacebuilding:Synthesis Report on Myanmar, Pakistan, South Africa and Uganda. UNICEF. https://pure.ulster.ac.uk/en/publications/the-integration-of-education-and-peacebuildingsynthesis-report-o-3

Smith Ellison, C. (2012). The role of education in peacebuilding: an analysis of five change theories in Sierra Leone, Compare: A Journal of Comparative and International Education 2012, 1-22, Routledge.

https://pure.ulster.ac.uk/ws/portalfiles/portal/11343527/CCOM_A_Smith_Ellison.pdf 
UNESCO (2011). The hidden crisis: Armed conflict and education. UNESCO.

https://en.unesco.org/gem-report/report/2011/hidden-crisis-armed-conflict-and-education

UNESCO (2015). Education for all global monitoring report: Policy paper 21: Humanitarian aid foreducation: why it matters and why more is needed. UNESCO.

https://unesdoc.unesco.org/ark:/48223/pf0000233557

Wallner, C. (2020) Preventing and Countering Violent Extremism Through Education Initiatives:Assessing the Evidence Base. Royal united Services Institute for Defence and SecurityStudies (RUSI). https://rusi.org/publication/occasional-papers/preventing-andcountering-violent-extremism-education

Wong, M. S. (2019). The Peace Dividend of Valuing Non-Dominant Languages in Languagein-Education Policies in Myanmar. FIRE: Forum for International Research in Education. 5(3). https://fire-ojs-ttu.tdl.org/fire/index.php/FIRE/article/view/143 